\title{
The effect of salinity on osmoregulation and development of the juvenile fat snook, Centropomus parallelus (POEY)
}

\author{
Sterzelecki, FC. ${ }^{a *}$, Rodrigues, E. ${ }^{b}$ Fanta, E. ${ }^{a}$ and Ribeiro, CAO. ${ }^{a}$ \\ ${ }^{a}$ Setor de Ciências Biológicas, Departamento de Biologia Celular, Universidade Federal do Paraná, \\ Centro Politécnico, CEP 81531-990, Curitiba, PR, Brazil \\ ${ }^{b}$ Departamento de Bioquímica, Universidade de Taubaté, CEP 12030-180, Taubaté, SP, Brazil \\ *e-mail: sterzelecki@gmail.com \\ Received: February 3, 2012 - Accepted: September 3, 2012 - Distributed: August 31, 2013
}

(With 2 figures)

\begin{abstract}
Eurihaline fish support waters with different salt concentration. However, numerous studies have shown that salinity can affect fish development. Thus, the effect of salinity change from 20 to 5 and 35 on survival, weight, length, gill chloride cell ultrastructure and gill $\mathrm{Na}^{+}, \mathrm{K}^{+}$ATPase activity was evaluated in Centropomus parallelus following short-term (6, 24 and 96 hours) and long-term exposure (30 and 60 days). Salinity did not affect $C$. parallelus survival, final weight and length. The quantity of chloride cells increased visibly at salinities of 5 and 35, with the cells exhibiting the typical features of uptake and secretory cells, respectively. $\mathrm{Na}^{+}, \mathrm{K}^{+}$ATPase activity in the gill of the $C$. parallelus was significantly greater at a salinity of 5 than at a salinity of 20 or 35 after 96 hours, but not after 30 or 60 days. These results indicate that salinity change from high to low salt water induces gill chloride cell and $\mathrm{Na}^{+}, \mathrm{K}^{+}$ ATPase activity adaptations after short-term exposure. However, after long-term exposure at salinity 5 , gill $\mathrm{Na}^{+}, \mathrm{K}^{+}$ ATPase activity is no more necessary at high levels. The increase in salinity to 35 does not induce significant change in gills. Juveniles of $C$. parallelus may thus be capable of acclimating to salinities of 5 to 35 for 60 days without significant effects on development.
\end{abstract}

Keywords: Centropomus parallelus, chloride cell, osmoregulation, $\mathrm{Na}^{+}, \mathrm{K}^{+}$ATPase.

\section{O efeito da salinidade sobre a osmoregulação e o desenvolvimento do juvenil de robalo-peva, Centropomus parallelus (POEY)}

\section{Resumo}

Peixes eurihalinos suportam águas com diferentes concentrações de sal. Contudo, muitos estudos têm mostrado que a salinidade pode afetar o desenvolvimento do peixe. Portanto, o efeito da mudança de salinidade de 20 para 5 e 35 na taxa de sobrevivência, peso, comprimento, morfologia das células de cloreto branquiais e atividade da $\mathrm{Na}^{+}, \mathrm{K}^{+} \mathrm{ATPase}$ foram avaliadas no Centropomus parallelus após curto (6, 24 e 96 horas) e longo tempo de exposição (30 e 60 dias). A salinidade não afetou a sobrevivência, o peso e comprimento final do robalo-peva. A quantidade de células de cloreto aumentou visivelmente nas salinidades 5 e 35, exibindo morfologias típicas de células que absorvem e secretam sal, respectivamente. A atividade da $\mathrm{Na}^{+}, \mathrm{K}^{+}$ATPase nas brânquias do C. parallelus foi significativamente maior na salinidade 5 do que nas salinidades 20 ou 35 após 96 horas, mas não após 30 e 60 dias. Esses resultados indicam que a mudança de alta para baixa salinidade provoca adaptações nas células de cloreto e na atividade da $\mathrm{Na}^{+}, \mathrm{K}^{+}$ATPase branquial em curto prazo. Contudo, após longa exposição na salinidade 5, a alta atividade da $\mathrm{Na}^{+}, \mathrm{K}^{+} \mathrm{ATPase}$ branquial não é mais necessária. $\mathrm{O}$ aumento de salinidade para 35 não induz mudanças significativas nas brânquias. Portanto, juvenis de C. parallelus possuem a capacidade de aclimatação nas salinidades de 5 a 35 sem efeitos significativos no desenvolvimento após 60 dias.

Palavras-chave: Centropomus parallelus, célula de cloreto, osmoregulação, $\mathrm{Na}^{+}, \mathrm{K}^{+} \mathrm{ATPase}$.

\section{Introduction}

The fat snook, Centropomus parallelus, is important for commercial and recreational fisheries as well as for aquaculture. This fish has been considered to be a good candidate for cultivation due to its resistance to diseases, satisfactory growth rate and suitability for human consumption. Although technology for the mass production of juvenile $C$. parallelus is currently available, Cerqueira and Tsuzuki (2009) appointed that further research is needed to reach the cost-effective growth-out technology. 
The fat snook is a species of the genus Centropomus that lives in and around estuarine waters located in southeastern Florida to the southern coast of Brazil (Rivas, 1986). Although juveniles of $C$. parallelus are naturally found in a wide salinity environment, it has been shown that salinity does affect fish development (Boeuf and Payan, 2001). In previous experiments, salinity specifically affected $C$. parallelus food intake, growth (Rocha et al., 2005) and digestive enzyme activity (Tsuzuki et al., 2007b). Nevertheless, the relationship between the osmoregulatory system and development at different salinities has yet to be explored in C. parallelus. Several studies have associated the rapid growth of some species with a reduction in osmoregulatory costs (Boeuf and Payan, 2001; Sampaio and Bianchini, 2002; Laiz-Carrión et al., 2005).

The environmental salinity different from the internal osmotic concentration of teleost fish provokes loss or gain of salt and water. To maintain the ionic concentration of body fluids, the osmoregulatory organs work together (McCormick, 2001). The gills are probably the organs that consume the most energy during osmoregulation (Sangiao-Alvarellos et al., 2003). More specifically, the gill $\mathrm{Na}^{+}, \mathrm{K}^{+}$ATPase, located mainly in chloride cells, requires energy input and plays an important role in osmoregulation in both hyperosmotic (Jobling, 1995; Evans et al., 2005) and hyposmotic (Evans, 2008; Parks et al., 2008) environments. The activity of this ATPase spends at least half of the energy consumed during $\mathrm{Na}^{+} / \mathrm{H}^{+}$exchange in ionocytes (Kirschner, 2004). For this reason, $\mathrm{Na}^{+}, \mathrm{K}^{+}$ATPase is considered to be a good biomarker of osmoregulation in teleosts. Understanding the activity of this pump at different salt concentrations may help to clarify the appropriate salinity for farm juvenile fat snooks. The goal of the present study was to assess the relationship between $\mathrm{Na}^{+}, \mathrm{K}^{+}$ATPase activity, chloride cell ultrastructure, survival, final weight and length in C. parallelus following acclimation to different salinities.

\section{Materials and Methods}

\subsection{Experimental design}

The experiment was conducted in February (experiment I) and repeated under the same conditions in May, 2007 (experiment II). A total of 328 juvenile of $C$. parallelus were obtained from the Marine Fish Culture Laboratory (LAPMAR) at the Universidade Federal de Santa Catarina, Brazil. Both trial fish derived from the same broodstock, but from a different spawning time. They were studied 65 days after hatching, weighing $0.14 \pm 0.05 \mathrm{~g}$ and $0.13 \pm 0.04 \mathrm{~g}$ (mean $\pm \mathrm{SD}$ ) in experiment I and experiment II, respectively. They were transported to the Universidade Federal do Paraná and separated into three $100-\mathrm{L}$ glass aquariums filled with water at a salinity of 20, at a stocking density of 0.6 fish/L. Filtered dechlorinated tap water and CORELIFE ${ }^{\circledR}$ artificial salt were used to reach the desired salinity, which was confirmed using a refractometer $( \pm 1)$. Over an acclimation period of nine days, low levels of total-ammonianitrogen (TAN), nitrite and nitrate $(0.3$ to $0.6 \mathrm{mg} / \mathrm{L}$, $0.1 \mathrm{mg} / \mathrm{L}$ and $5-10 \mathrm{mg} / \mathrm{L}$, respectively) were maintained using a recirculation system with biological and mechanical filters. Dissolved oxygen was maintained between 4-5 $\mathrm{mg} / \mathrm{L}$ and $\mathrm{pH}$ at 8-8.2. The snooks were kept at $26 \pm 2{ }^{\circ} \mathrm{C}$, under natural photoperiod and fed once a day to satiation with adult of frozen Artemia. After feeding, all waste at the bottom of the tank was siphoned.

Following the acclimation period, the salinity was progressively increased and decreased in two aquariums to 35 and 5, respectively. The third group was cultivated at a salinity of 20, although the same volume of water was exchanged as in the other groups to maintain consistency. Additional chemical properties of the water were maintained at levels similar to those achieved during the acclimation period by monitoring with $\mathrm{Sera}^{\mathrm{B}}$ Kit and changing weekly $20 \%$ of water.

\subsection{Fish measurements and sample collection}

From experiment I, 54 to 58 fish in each aquarium started the trial. After acute (6, 24 and 96 hours) and chronic period (30 and 60 days) of salinity change, 3 to 10 fish were sampled. From the experiment II, 51 to 57 fish in each aquarium started the trial and 2 to 10 fish were sampled at the same time point as before. For both experiments, sampled fish were anesthetised with benzocaine $(50 \mathrm{mg} / \mathrm{L})$, weighed, measured and sacrificed to evaluate $\mathrm{Na}^{+}, \mathrm{K}^{+}$ATPase activity and gill chloride cells. After 96(t0) hours, 30 (t30) and 60 (t60) days all the fish were measured and weighed to biometric comparison (see Table I). The sampling variation occurred due to the sacrifice to biochemical analysis, mortality and cannibalism.

\section{3. $\mathrm{Na}^{+}, \mathrm{K}^{+}$ATPase activity}

The branchial arches from sacrificed fish, with the exception of the second arch, were frozen immediately in liquid nitrogen and stored at $-80^{\circ} \mathrm{C}$ until the biochemical assays were performed. A method obtained from McCormick (1993) was used to evaluate $\mathrm{Na}^{+}, \mathrm{K}^{+}$ATPase activity. The gills were homogenised in $100 \mu \mathrm{L}$ of SEI buffer ( $\mathrm{pH} 7.5 ; 250 \mathrm{mM}$ sucrose; $10 \mathrm{mM} \mathrm{Na}_{2}$ EDTA and $50 \mathrm{mM}$ imidazole) and $50 \mu \mathrm{L}$ of SEID $(0.1 \mathrm{~g}$ sodium deoxycholic acid in $33.3 \mathrm{~mL}$ of SEI). Following homogenisation, the gills were centrifuged at 5,000 $\mathrm{g}$ for $2 \mathrm{~min}$. The insoluble material was separated, and $10 \mu \mathrm{L}$ of supernatant in duplicate was added into microplate wells to $200 \mu \mathrm{L}$ of the reaction mixture containing $50 \mathrm{mM}$ imidazole ( $\mathrm{pH} 7.5$ ), $189 \mathrm{mM} \mathrm{NaCl}, 10.5 \mathrm{mM}$ $\mathrm{MgCl}_{2}, 2.86 \mathrm{U} / \mathrm{mL} \mathrm{LDH}, 3.57 \mathrm{U} / \mathrm{mL}$ PK, $2 \mathrm{mM}$ PEP, $150 \mu \mathrm{M}$ NADH and $0.5 \mathrm{mM}$ ATP. In addition, other two wells of microplate were filled with the same mixture plus $0.5 \mathrm{mM}$ ouabain. NADH oxidation levels at $28{ }^{\circ} \mathrm{C}$ were used to quantify $\mathrm{Na}^{+}, \mathrm{K}^{+}$ATPase activity by measuring absorbance at $340 \mathrm{~nm}$ using a microplate reader and then subtracting the total activity without ouabain 
from the total activity with ouabain. A Bradford (1976) assay was also used to evaluate the total protein concentration. $\mathrm{Na}^{+}, \mathrm{K}^{+}$ATPase activity was expressed as micromoles of ADP per milligramme of protein per hour.

\subsection{Ultrastructure}

The second gill arch was sectioned and fixed in a solution of $2.5 \%$ glutaraldehyde, $2 \%$ paraformaldehyde and $0.2 \mathrm{M}$ cacodylate $(\mathrm{pH} 7.2)$ for 24 hours, and postfixed in $1 \%$ osmium tetroxide and $0.1 \mathrm{M}$ cacodylate buffer for 2 hours. Samples were contrasted in 2\% uranyl, dehydrated in graded acetone and embedded in PolyEmbed 812. Ultra-thin sections were contrasted in $5 \%$ uranyl acetate and lead citrate. Electron micrographs were then captured using the JEOL TEM 1200 EXII transmission electron microscope.

\subsection{Statistical analysis}

Because the body measurement data did not meet the requirements of variance analysis (ANOVA), a Kruskal-Wallis non-parametric test was used instead. Two-way ANOVA was used to test for salinity and time effects on $\mathrm{Na}^{+}, \mathrm{K}^{+}$ATPase activity. Significant differences were compared using a Bonferroni post-test $(\mathrm{p}<$ $0.05)$. Survival was compared after 30 and 60 days of salinity challenge. We pooled the data for each salinity because no significant differences were found between experimental aquariums at any salinity or at different sampling times.

\section{Results}

All of the experimental groups of C. parallelus initially had similar weights and after 60 days, mean weights were significantly higher. However, there was no difference between salinity treatments. Survival was also not significantly affected by salinity (see Table 1).

Chloride cells can be easily recognised by their large numbers of mitochondria, which may be visualised by electron microscopy (see Figure 1). After 24 hours at a salinity of 5 , the number and size of the ionocytes increased visibly in the interlamellar area (see Figure 1A). The apical membrane surface increased and at times projected into the external medium. After 96 hours, some chloride cells were observed with a convex apical membrane in the secondary lamella (see Figure 1B). During the whole experiment, fish exposed to a salinity of 20 exhibited few gill chloride cells in the interlamellar region (see Figure 1C). The apical membrane in this salinity invaginated to form a crypt with an opening smaller than that of a membrane exposed to a hyposmotic environment (see Figure 1D). The quantity of chloride cells increased slightly after a 96-hour exposure to a salinity of 35 , while after 60 days, the number was even higher (see Figure 2E). The apical membrane showed a deep crypt associated with accessory cells (see Figure 1F).

Ninety-six hours after a change in the surrounding environment's salinity, the $\mathrm{Na}^{+}, \mathrm{K}^{+}$ATPase activity in the gill of the $C$. parallelus was significantly greater at a salinity of $5\left(15.39 \pm 8.62 \mu \mathrm{mol}\right.$ ADP.mg protein $\left.{ }^{-1} \cdot \mathrm{h}^{-1}\right)$ than at salinities of $20(3.22 \pm 1.28 \mu \mathrm{mol}$ ADP.mg pro$\left.\operatorname{tein}^{-1} \cdot \mathrm{h}^{-1}\right)$ and $35(4.743 \pm 1.91 \mu \mathrm{mol}$ ADP.mg pro$\left.\operatorname{tein}^{-1} \cdot h^{-1}\right)$. However, after 30 or 60 days, there was no difference in ATPase activity between treatments (see Figure 2).

\section{Discussion}

C. parallelus survival was not affected 30 and 60 days after salinity challenge. This finding indicates excellent resistance to a wide range of salt concentrations. Previous studies have also demonstrated no difference in the survival rates of $C$. parallelus reared in environments of different salinities (Tsuzuki et al., 2007b). Nevertheless, an abrupt salinity change should be avoided due to the high mortality rate observed when small juveniles are directly transferred from seawater to freshwater (Tsuzuki et al., 2007a).

Table 1 - Average weight, length, standard and length ( \pm S.D.) of juveniles of Centropomus parallelus pooled from both experiments.

\begin{tabular}{lcccccc}
\hline Salinity & Period & $\mathbf{n}$ & Weight $(\mathbf{g})$ & Total length $(\mathbf{c m})$ & Standard length (cm) & Survival rate (\%) \\
\hline 5 & $\mathrm{t}(0)$ & 50 & $0.12 \pm 0.04$ & $2.48 \pm 0.27$ & $1.92 \pm 0.27$ & \\
& $\mathrm{t}(30)$ & 25 & $0.23 \pm 0.06$ & $3.01 \pm 0.26$ & $2.33 \pm 0.17$ & 69.10 .58 \\
& $\mathrm{t}(60)$ & 10 & $0.61 \pm 0.23$ & $4.11 \pm 0.67$ & $3.26 \pm 0.56$ & $85.7 \pm 2.01$ \\
& $\mathrm{t}(0)$ & 59 & $0.13 \pm 0.04$ & $2.51 \pm 0.30$ & 1.960 .25 & $74.5 \pm 0.30$ \\
& $\mathrm{t}(30)$ & 42 & $0.19 \pm 0.07$ & $2.85 \pm 0.33$ & $2.19 \pm 0.28$ & $80.1 \pm 0.45$ \\
& $\mathrm{t}(60)$ & 18 & $0.45 \pm 0.23$ & $3.53 \pm 0.56$ & $2.77 \pm 0.48$ & $74.1 \pm 1.88$ \\
& $\mathrm{t}(0)$ & 47 & $0.15 \pm 0.05$ & $2.66 \pm 0.29$ & $2.07 \pm 0.28$ & $84.5 \pm 0.01$ \\
\hline
\end{tabular}

Initial (t0), 30 (t30) and 60(t60) days started trial. There were no significant differences ( $\mathrm{p}>0.01)$. 

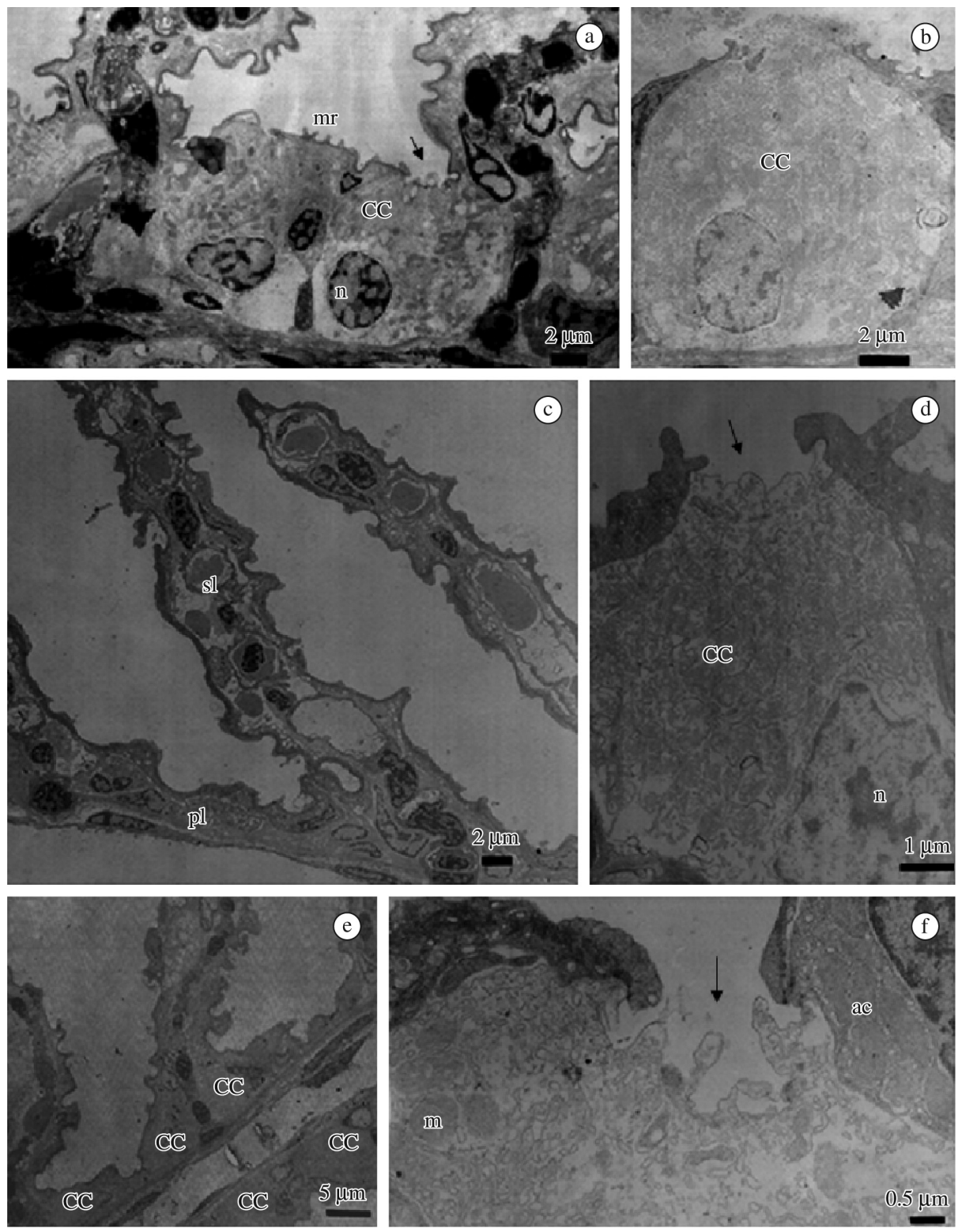

Figure 1 - Transmission electron microphotograph of C. parallelus gill epithelium at salinities of 5 (A-B), 20 (C-D) and 35 (E-F). (A) After 24 hours, an increased number of chloride cells (CC) was observed between the secondary lamellae. Note the broad apical region ( $\uparrow$ ). Nucleus (n). Microridges (mr). (B) After 96 hours, a large number of CC was found in the secondary lamella with a wavy-convex apical membrane. (C) After 60 days, the number of chloride cells was not expressive. Primary lamellae (pl). Secondary lamellae (sl). (D) Chloride cells were scarce, with the few that were present exhibiting shallow apical crypt $(\uparrow)$ and located in the interlamellar region. (E) After 60 days, the number of chloride cells increased between the secondary lamellae. (F) Detail of the deep apical crypt with projections ( $\uparrow$ ) and an adjacent accessory cell (ac) after 24 hours. Mitochondria $(\mathrm{m})$.

The effect of salinity on the growth of several species of fish has previously been tested. Although salinity level usually influences growth, it occasionally does not have an effect (Boeuf and Payan, 2001). For example, Dicentrarchus labrax (Rubio et al., 2005), Trinectes maculatus fasciatus (Peterson-Curtis, 1997) and Lutjanus griseus (Wuenschel et al., 2004) have shown no difference in growth after salinity challenge. In the present study, we have not verified the specific growth rate of the $C$. parallelus, because of the low number of replicates. Nevertheless, the weight and length was compared and showed no statistic difference after 60 days of exposure to altered salinity. Similarly, Tsuzuki et al. (2007b) observed no significant differences in $C$. parallelus 


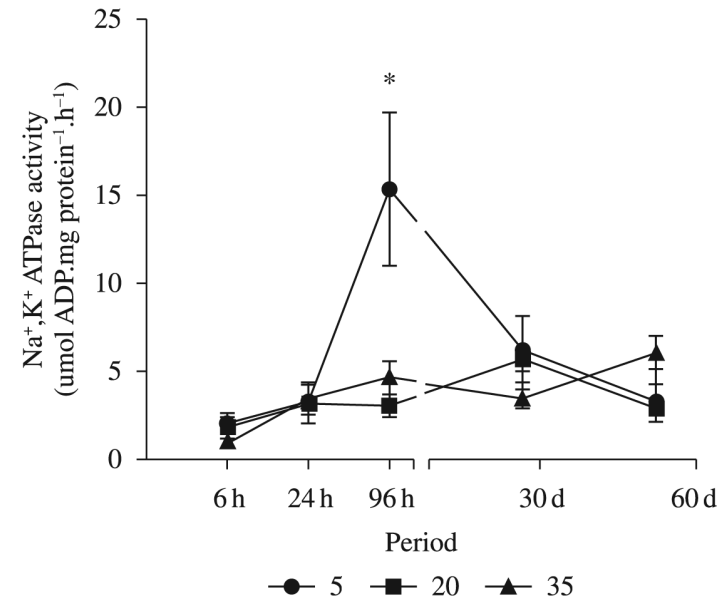

Figure $2-\mathrm{Na}^{+}, \mathrm{K}^{+}$ATPase activity in Centropomus parallelus after 60 days at salinities of 5, 20 and 35 (mean \pm S.E.M., $\mathrm{n}=4-6)$. (*) indicates a significant difference between treatment groups $(\mathrm{p}<0.05)$.

growth after 50 days at a salinity of 5,15 or 35 and the final mean weight was similar from the individuals of the present study, between 0.84 to $0.91 \mathrm{~g}$. Other experiments with juveniles of $C$. parallelus also observed this weight range (Corrêa and Cerqueira, 2007; Ferraz et al., 2011) at this stage. These results indicate that juvenile $C$. parallelus are capable of acclimating to a wide range of salinity without significant effects on growth.

Depending on the salinity of the surrounding environment, gill chloride cells can assume different morphologies in teleosts. Chloride cells with a deep apical crypt are usually associated with hyperosmotic medium, while those with a broad apical region and microvilli are associated with hyposmotic waters (Sakamoto and McCormick, 2006). Evidence suggests that there is a correlation between chloride cell subtype and osmoregulatory function, such that the hyperosmotic subtype is involved in salt secretion and the hyposmotic subtype is involved in salt uptake (Hwang and Lee, 2007). In the current study, C. parallelus gill chloride cells responded to salinity as expected, assuming the morphology observed in the majority of other teleosts. It was possible to observe the hyposmotic subtype in $C$. parallelus gills after 24 hours at a salinity of 5 (Fig. 2B). The hyposmotic subtype has a larger apical membrane to enable increased ion absorption in low-salinity waters (Fernandes and Perna-Martins, 2002). After 96 hours at a salinity of 5, $C$. parallelus chloride cells were found in the secondary lamella. This result is consistent with what is observed when many teleost species are transferred to freshwater (Perry, 1998). In contrast, hyperosmotic medium at a salinity of 20 or 35 did not promote this hyposmotic cell subtype in the secondary lamella of $C$. parallelus gills. These results suggest that the chloride cell, with a broad opening in the secondary lamella of C. parallelus, is involved in salt uptake. Consistent with this concept, at a salinity of 20 , the juvenile $C$. parallelus exhibited charac- teristic hyperosmotic chloride cells, which are responsible for salt extrusion. Increasing the salinity to 35 provoked a noticeable proliferation of these chloride cells in the interlamellar space after 60 days. Increasing the salt concentration augments the number of gill chloride cells in other species as well, such as the Japanese eel (Wong et al., 1999), killifish (Lima and Kültz, 2004) and sturgeon (Martínez-Álvares et al., 2005). Thus, the salinity change to hypotonic and hypertonic waters provoke morphological adaptations on gill chloride cells of $C$. parallelus as does in many eurihaline species.. Carmona et al. (2004) suggested that these modifications involve an increase in cellular activity.

The gill $\mathrm{Na}^{+}, \mathrm{K}^{+}$ATPase plays a large role in teleost osmoregulation and has been shown to be involved in both seawater (McCormick et al., 1989; Sardella and Brauner, 2008) and freshwater (Sampaio and Bianchini, 2002; Laiz-Carrión et al., 2005; Nebel et al., 2005) tolerance in many species. In addition, this enzyme accounts for the most energy expenditure within the cell (Marshall and Bryson, 1998). In the present study, C. parallelus at a salinity of 5 showed an augmentation at 96 hours, followed by a return to initial levels after 30 days. This oscillation indicates that high ATPase activity is only required for the initial acclimatisation to low salinity. McCormick and Bradshaw (2006) pointed out that some alterations in teleost gill membrane permeability and ion transport can occur after long periods in hyposmotic environments and that this adaptation is mediated by the hormone prolactin. It is possible that the gill ion permeability of C. parallelus is also altered after long-term exposure to low salinity, enabling reduction of $\mathrm{Na}^{+}, \mathrm{K}^{+}$ ATPase activity. Salinity 20 and 35 induced no significant changes on $\mathrm{Na}^{+}, \mathrm{K}^{+}$ATPase activity, although the augment in salinity to 35 has increased the number of chloride cells after 60 days. As evidenced by Foskett et al. (1983), seawater adaptation provokes increases in the size and/or number of chloride cells, which is related to an increased activity in gill $\mathrm{Na}^{+}, \mathrm{K}^{+}$ATPase in most, but not all species. For instance, at the end of the 84-day experimental period, Umbrina cirrosa showed no difference on $\mathrm{Na}^{+}, \mathrm{K}^{+}$ATPase activity at low and high salinity water, although the number of chloride cell had increased (Mylonas et al., 2009). The enhanced number of gill chloride cell suggests that a reduction in branchial water permeability decreases water loss and permit a low activity of $\mathrm{Na}^{+}, \mathrm{K}^{+}$ATPase.

In summary, a salinity of 5 provoked a significant change in $\mathrm{Na}^{+}, \mathrm{K}^{+}$ATPase activity after 96 hours, which coincided with morphological modifications in the gill chloride cells. Seawater acclimation induced only chloride cell proliferation. These results indicate that $C$. parallelus gill activity for the purpose of osmoregulation may have been higher at a salinity of 5 than at other salinities during short-term acclimation, but not after long-term exposure. Thus, juvenile $C$. parallelus are capable of acclimatising and farming at salinities of 5 and 35 without significant effects on weight and length after 60 days. However, additional studies investigating the ef- 
fects of salinity on the osmoregulatory and non-osmoregulatory organs of $C$. parallelus over longer periods are necessary to better understand the direct and indirect influences of salinity on the growth phase.

\section{Acknowledgments}

The authors would like to thank the staff of LAPMAR at the Universidade de Santa Catarina for providing the individual fat snooks used in the present study and the researchers at the Universidade de Taubate and the Universidade Federal do Paraná for lending their facilities and equipment. We thank Dr. Stephen D. McCormick for sharing his laboratory protocols and for his assistance with this study.

\section{References}

BOEUF, G. and PAYA, P., 2001. How should salinity influence fish growth? Comparative Biochemistry and PhysiologyPart C: Pharmacology and Toxicology, vol. 130, p. 411423.

BRADFORD, MM., 1976. A rapid and sensitive method for the quantitation of microgram quantities of protein utilizing the principle of protein-dye binding. Analytical Biochemistry, vol. 72, p. 248-254

CARMONA, R., GARCIA-GALLEGO, M., SANZ, A., DOMEZAÍN, A. and OSTOS-GARRIDO, MV., 2004. Chloride cells and pavement cells in gill epithelia of Acipenser naccarii: ultrastructural modifications in seawateracclimated specimens. Journal of Fish Biology, vol. 64, p. 553-566.

CERQUEIRA, VR. and TSUZUKI, MY., 2009. A review of spawning induction, larviculture, and juvenile rearing of the fat snook, Centropomus parallelus. Fish Physiology and Biochemistry, vol. 35, p. 17-28.

CÔRREA, CF. and CERQUEIRA, VR., 2007. Effects of stocking density and size distribution on growth, survival and cannibalism in juvenile fat snook (Centropomus parallelus Poey). Aquaculture Research, vol. 38, p. $1627-1634$.

EVANS, DH., 2008. Teleost fish osmoregulation: What have we learned since August Krogh, Homer Smith, and Ancel Keys? American Journal of Physiology-Regulatory Comparative Integrative and Physiology, vol. 295, p. 704-713.

EVANS, DH., PIERMARINI, PM. and CHOE, KP., 2005. The Multifunctional Fish Gill: Dominant Site of gas exchange, osmoregulation, acid-base regulation, and excretion of nitrogenous waste. Physiology Reviews, vol. 85, p. 97-177.

FERNANDES, MN. and PERNA-MARTINS, SA., 2002. Chloride cell responses to long-term exposure to distilled and hard water in the gill of the armored catfish, Hypostomus tietensis (Loricariidae). Acta Zoologica (Stockholm), vol. 83, p. 321-328.

FERRAZ, EM., CARVALHO, GCS., SHAEFER, ALC., NARAHARA, MY. and CERQUEIRA, VR., 2011. Influência da temperatura de cultivo sobre crescimento e diferenciação sexual de robalo-peva, Centropomus parallelus Poey, 1860. Revista Brasileira de Engenharia de Pesca, vol. 6, p.1-16

FOSKETT, JK., BERN, HA., MACHEN, TE. and CONNER, M., 1983. Chloride cells and the hormonal control of teleost fish osmoregulation. Journal of experimental Biology, vol. 106, p. 255-281.
HWANG, PP. and LEE, TH., 2007. New insights into fish ion regulation and mitochondrion-rich cells. Comparative Biochemistry and Physiology - Part A: Molecular and Integrative Physiology, vol. 148, p. 479-497.

JOBLING, M., 1995. Enviromental biology of fishes. London: Chapman and Hall. 445 p.

KIRSCHNER, LB., 2004. The mechanism of sodium chloride uptake in hyperregulating aquatic animals. Journal of Experimental and Biology, vol. 207, p. 1439-1452.

LAIZ-CARRIÓN, R., SANGIAO-AVARELLOS, S., GUZMÁN, JM., DEL RIO, MPMJ., SOENGAS, L. and MANCERA, JM., 2005. Growth performance of gilthead sea bream Sparus aurata in different osmotic conditions: implications for osmoregulation and energy metabolism. Aquaculture, vol. 250, p. 849-861.

LIMA, RN. and KÜLTZ, D., 2004. Laser scanning cytometry and tissue microarray analysis of salinity effects on killifish chloride cells. Journal of Experimental Biology, vol. 207, p. 1729-1739.

MARSHALL, WS. and BRYSON, SE., 1998. Transport Mechanisms of Seawater Teleost Chloride Cells: An Inclusive Model of a Multifunctional Cell. Comparative Biochemistry and Physiology - Part A Molecular and Integrative Physiology, vol. 119, p. 97-106.

MARTÍNEZ-ÁLVAREZ, RM., SANZ, A., GARCIA-GALLEGO, M., DOMEZAIN, A., DOMEZAIN, J., CARMONA, RV., OSTOS-GARRIDO, M. and MORALES, AE., 2005. Adaptive branchial mechanisms in the sturgeon Acipenser naccarii during acclimation to saltwater. Comparative Biochemistry and Physiology-Part A: Molecular and Integrative Physiology, vol. 141, p. 183-190.

McCORMICK, SD., 1993. Methodos for nonlethal gill biopsy and measurement of $\mathrm{Na}^{+}, \mathrm{K}^{+}$ATPase activity. Canadian Journal of Fisheries and Aquatic Sciences, vol. 50, p. 656-658.

-, 2001. Endocrine control of osmoregulation in teleost fish. American Zoologist, vol. 41, p. 781-794.

McCORMICK, SD. and BRADSHAW, D., 2006. Hormonal control of salt and water balance in vertebrates. General and Comparative Endocrinology, vol. 147, p. 3-8.

McCORMICK, SD., SAUNDERS, RL. and MACLNTYRE, AD., 1989. Mitochondrial enzyme and $\mathrm{Na}^{+}, \mathrm{K}^{+}$-ATPase activity, and ion regulation during parr-smolt transformation of Atlantic Salmon (Salmo Salar). Fish Physiology and Biochemistry, vol. 6, p. 231-241.

MYLONAS, CC., PAVLIDIS, M., PAPANDROULAKIS, N., ZAISS, MM., TSAFARAKIS, D., PAPADAKIS, IE. and VARSAMOS, S., 2009. Growth performance and osmoregulation in the shi drum (Umbrina cirrosa) adapted to different environmental salinities. Aquaculture, vol. 287, p. 203-210.

NEBEL, C., ROMESTAND, B., NÈGRE-SADARGEUS, G., GROUSSET, E., AUJOULAT, F., BACAL, JFB. and CHARMANTIER, G., 2005. Differential freshwater adaptation in juvenile sea-bass Dicentrarchus labrax: involvement of gills and urinary system. Journal of Experimental Biology, vol. 208, p. 3858-3871.

PARKS, SK., TRESGUERRES, M. and GOSS, GG., 2008. Theoretical considerations underlying $\mathrm{Na}^{+}$uptake mechanisms in freshwater fishes. Comparative Biochemistry and Physiology-Part C: Pharmacology and Toxicology, vol. 148, p. 411-418.

PERRY, SF., 1998. Relationships between branchial chloride cells and gas transfer in freshwater. Comparative Biochemistry and Physiology-Part A: Molecular and Integrative Physiology, vol. 119, p. 9-16. 
PETERSON-CURTIS, TL., 1997. Effects of salinity on survival, growth, metabolism, and behavior in juvenile hogchokers, Trinectes maculatus fasciatus (Achiridae). Environmental Biology of Fishes, vol. 49, p. 323-331.

RIVAS, LR., 1986. Systematic review of the perciform fishes of the genus centropomus. Copeia, vol. 3, p. 579-611.

ROCHA, AJ., GOMES, V., NGAN, PV., PASSO, SMJACR. and FURIA, RR., 2005. Metabolic demand and growth of juveniles of Centropomus parallelus as function of salinity. Journal of Experimental Marine Biology and Ecology, vol. 316, p. 157-165.

RUBIO, VC., SÁNCHEZ-VÁSQUEZ, FJ. and MADRID, JA., 2005. Effects of salinity on food intake and macronutrient selection in European sea bass. Physiology and Behavior, vol. 85 , p. 333-339.

SAKAMOTO, T. and McCORMICK, SD. 2006. Prolactin and growth hormone in fish osmoregulation. General Comparative Endocrinology, vol. 147, p. 24-30.

SAMPAIO, LA. and BIANCHINI, A., 2002. Salinity effects on osmoregulation and growth of the euryhaline flounder Paralichthys orbignyanus. Journal of Experimental Marine Biology and Ecology, vol. 269, p. 187-196.

SANGIAO-ALVARELLOS, SR., LAIZ-CARRIÓN, JM., GUZMÁN, MP., MARTIN DEL RÍO, MP., MIGUEZ, JM., MANCERA, JM. and SOENGAS, JL., 2003. Acclimation of $S$. aurata to various salinities alters energy me- tabolism of osmoregulatory and nonosmoregulatory organs. American Journal of Physiology Regulatory Integrative Comparative Physiology, vol. 285, p. 897-907.

SARDELLA, BA. and BRAUNER, CJ., 2008. The effect of elevated salinity on 'California' Mozambique tilapia (Oreochromis mossambicus x O. urolepis hornorum) metabolism. Comparative Biochemistry and PhysiologyPart C: Pharmacology and Toxicology, vol. 148, p. 430436.

TSUZUKI, MY., CERQUEIRA, VR., TELES, A. and DONEDA, S., 2007a. Salinity tolerance of laboratory reared juviniles of the fat snook Centropomus parallelus. Brazilian Journal of Oceanography, vol. 55, p. 1-5.

TSUZUKI, MY., SUGAI, JK., MACIEL, JC. FRANCISCO, CJ. and CERQUEIRA, VR., 2007b. Survival, growth and digestive enzyme activity of juveniles of the fat snook (Centropomus parallelus) reared at different salinities. Aquaculture, vol. 271, p. 319-325.

WONG, CKC. and CHAN, DKO., 1999. Chloride cell subtypes in the gill epithelium of Japanese eel Anguilla japonica. American Journal of Physiology-Regulatory, Integrative, Comparative and Physiology, vol. 277, p. 517-522.

WUENSCHEL, MJ., JUGOVICH, AR. and HARE, JA., 2004. Effect of temperature and salinity on the energetics of juvenile gray snapper (Lutjanus griseus): implications for nursery habitat value. Journal of experimental Marine Biology and Ecology, vol. 312, p. 333-347. 